each group as to how it can be most helpful. Many members of each group will have ideas, and perhaps "a pebble in his shoe" which he would like to cast out. After getting rid of these pebbles by explanation or adjustment, the first real step in satisfactory public relations will have been realized and the way for group cooperative efforts will be cleared. The more enduring efforts may then be emphasized and the groups will be ready to put them into effect. The reviewer is sorely tempted to develop the author's treatment of the ways in which each group may make its contributions but the limits of space must be observed. These paragraphs are provocative in thought and ideas.

For the permanent operation of the program, the participants must be made to feel that their work is effective and that their efforts are recognized and appreciated. This requires coherent planning, logical organization, continual assistance and guidance under a director of the consolidated program who works "as close to the administrator as his own skin."

The establishment of such a program may require from three to five years. The first year may be devoted to defining the institution's area of prestige through the administrator's personal thinking and through ideas gleaned from advisers among the faculty, trustees, students, alumni, and others. A nucleus of workers will develop during the first year, and during the second the nucleus will grow in size and begin to function. During the third year the programs will have developed and efforts to put them into operation will begin. In the fourth and fifth years the nuclei will expand greatly and will be steadily at work in well thought out programs which, if continued, will bring in steady dividends to the institution.

Whether or not all the points considered in the book are valid is of small consequence. Some few are doubtful. The book as a whole, however, is an important contribution to the field of public relations in educational institutions. It should be valuable to both the president and to the director of public relations. It should be on the director's shelves along with the more detailed books on the same subject by Benjamin Fine, Emerson Reck, and Stewart Harrall. These volumes are more or less manuals of publicity techniques whereas the volume under review is a comprehensive yet concise examination of the methods through which an educational institution can utilize its various component parts in developing and carrying on a well rounded, effective public relations program. These other titles implement rather than duplicate the contents of $\mathrm{Mr}$. Parsons' volume. All of them should be known to the college or university librarian, who as a responsible officer is an important link in the public relations program of the institution he represents.-W. Porter Kellam, University of North Carolina Library.

\title{
American Universities, Colleges, and Junior Colleges
}

American Universities and Colleges. $5^{\text {th }}$ ed. Edited by A. J. Brumbaugh. Washington, D.C., American Council on Education, 1948. 1054p.

American Junior Colleges. 2d ed. Edited by Jesse P. Bogue. Washington, D.C. American Council on Education, 1948. 537p.

Most librarians in academic institutions know of the usefulness of American Universities and Colleges. The first edition of this work, issued in 1928, contained data of 399 accredited institutions; the present fifth edition, of 820 institutions. The new edition has not only grown in the number of universities and colleges included; it has also grown in the amount of material included about the institutions. For example, specific information relating to veterans and foreign students has been added.

Information about the library in each institution is usually limited to size (in volumes), number of government documents held, number of periodicals received regularly, volumes added and funds spent for acquisitions during 1946-47, and special collections owned. Some of themajor institutions, such as Chicago, Columbia, and Yale have listed collections in considerable detail. No information, however, is available about the notable collections at Harvard.

Special note should be taken of the sections 
dealing with professional education in 19 fields. Each field is discussed by a national officer, and 1515 accredited professional and technical schools are listed. Education for librarianship is reviewed by Anita M. Hostetter.

Attention should also be called to the first three chapters of the volume. Chapter I, by M. M. Chambers, is concerned with the overall problem of "Education in the United States," and considers such matters as federal policy toward education, the Office of Education, types of organizations and programs, philanthropic foundations and their relations to education, and associations of colleges and universities. John Dale Russell is the author of the second chapter, "The American College." In the section on the library, Dr. Russell uses figures of the Office of Education for 1939-40. These were the most recent available. As a result, the statements concerning the total book holdings and expenditures of college libraries are undoubtedly far below present figures. Other topics discussed by Dr. Russell are interlibrary loans and microphotography. In his comments on book collecting, he observes:

[Some libraries] are attempting to divide the responsibility for large-scale collecting within fields of common interest. Such a development, however, awaits a corresponding division of responsibility in the field of graduate instruction, and cannot proceed without it.

This is an admonition that librarians need to bear in mind in organizing cooperative acquisitions programs.

The third chapter, "The American University," by Donald H. Daugherty, includes much useful material for the university librarian. There is no attempt, however, to discuss the university library (reference is made to the comments of Dr. Russell). Tabular summaries of doctorates by institu- tion and subject and by institution and year (1939-40 through 1945-46) bring up to date similar material found in the fourth edition of the volume.

Growth in the development of junior colleges is also exhibited in American Junior Colleges, by Jesse P. Bogue, who is executive secretary of the American Association of Junior Colleges. The first edition of this work, issued in 1940, considered 494 accredited junior colleges. The 1948 edition includes material about 564 accredited institutions.

Part I of this volume contains discussions of types of junior colleges, development of the junior college movement, present status and trends of the junior college movement, and accreditation of junior colleges. Accreditation standards and practices, including both regional and state accrediting agencies, are also provided.

The information given regarding the library under each institution differs somewhat from that provided in American Universities and Colleges. Data concerning type of library space (separate building or otherwise), seating capacity, and number of full-time and part-time library staff are provided in addition to facts about collections, periodicals, budget, and volumes added 1946-47.

In both of these volumes, the librarian has sources of data regarding America's higher academic institutions which he can get at conveniently and easily. The discussions, the institutional exhibits, the standards, the classified lists of schools in the appendices of both volumes, the tabular presentation of curricula offered by junior colleges-these features, among others, render these volumes edited by Brumbaugh and Bogue exceptionally valuable reference guides for college and research libraries.-Maurice F. Tauber, Columbia University.

\section{Book Collecting}

Taste and Technique in Book-Collecting; a Study of Recent Delopments in Great Britain and the United States. By John Carter. New York, Bowker, 1948, xxiii, 203p. \$5.00.

If you relish good writing about books you will hasten to read this one, for it is written with sense, grace and knowledge. It avoids the defects of many books about books of being condescendingly elementary or sentimentally overwritten. It is neither glibly technical nor chummily anecdotal, and might be called a sophisticated big brother to Storm and Peckham's Invitation to Book Collecting. 